\title{
Efficiency of Land Use in Smallholder Palm Oil Plantations in Indonesia: A Stochastic Frontier Approach
}

\author{
Dyah Wulan Sari ${ }^{1}$, Faqih Nur Hidayat ${ }^{1,}{ }^{*}$, Irawati Abdul ${ }^{1}$ \\ ${ }^{1}$ Faculty of Economy and Business, Airlangga University, Jl. Airlangga No.4. Surabaya 60286, Indonesia. \\ * Correspondence author: faqih.nur.hidayat-2018@feb.unair.ac.id
}

\begin{abstract}
Indonesia has become the country with the largest palm oil production. However, the level of productivity of oil palm per land in Indonesia tends to remain stagnant. The main objective of this study is to evaluate oil palm lands of smallholders that experience land inefficiency. In analyzing land efficiency, this study used cross-section data obtained from Statistics Indonesia (BPS). This study uses an input distance function approach with stochastic frontier analysis tools. Our estimation results found that on average, smallholders oil palm plantations face land inefficiency. The land inefficiency of smallholder oil palm plantations is not proportional to the negative impacts it has caused. The intensification of oil palm plantation land is one of the ways to reduce the rate of deforestation and optimize available land. Land intensification can be done through the selection of potential lands, renewal programs for oil palm trees, supporting facilities and infrastructure, and plantation technology development.
\end{abstract}

Keywords: oil palm; efficiency; input distance function; stochastic frontier

\section{Introduction}

Indonesia is the world's largest producer and exporter of palm oil. More than fifty percent of the world's palm oil needs are met by Indonesia (FAO, 2017). Throughout 2014 to 2018, the increase in Indonesian palm oil exports reached 2.07 percent to 19.45 percent per year or grew by 24.37 million tons in 2014 and increased to 29.67 million tons in 2018. The increase in world palm oil demand was also supported by an increase in the amount of palm oil production. In 2014-2018, oil palm production has increased in the range of 1.35 percent to 10.96 percent. In 2014, palm oil production reached 29.28 million tons, increased to 34.94 million tons in 2017 or increased by 19.34 percent and is estimated to have increased by 4.74 percent to 36.59 million tons in 2018 (BPS, 2018).

The increase in demand for Indonesian palm oil was responded by the Government of Indonesia by granting permits to expand oil palm plantations through Regulation of the Minister of Agriculture of the Republic of Indonesia No. 21 of 2017. This regulation has implications in increasing the amount of land used. During the period 2014-2018, Indonesia's land expansion tended to increase, ranging from 2.77 percent to 10.55 percent per year. In 2014, oil palm plantation land was recorded at 10.75 million hectares and was estimated to have increased to 12.76 million hectares in 2018 . Based on the status of concessions in 2017, the private sector amounted to 6.05 million hectares (48.83\%), while 5.70 million hectares $(46.01 \%)$ were cultivated by smallholder plantations and 0.64 million hectares (5.15\%) were cultivated by state oil palm plantations. In 2018 , private oil palm land increased to 6.36 million hectares $(49.81 \%)$, smallholder plantations increased to 5.81 million hectares $(45.54 \%)$ and 0.59 million hectares $(4.56 \%)$ were cultivated by state plantations (BPS, 2018).

However, expansion of oil palm land has had a negative impact on the environment. The issue of deforestation has become a longstanding issue in Indonesia. Forest change due to deforestation has an impact on the loss of biodiversity and climate change, which has become a political issue for increasing land expansion (Wicke, 2011). Wilcove and Koh (2010), in their study stated that the biggest threat of loss of biodiversity is in Southeast Asia. For example, in Malaysia, at least 1,040,000 ha of forest have been converted from 1990 to 2005, whereby studies indicate that forest land 
restoration caused by productive forests recovers faster over time within the scope of the region's native fauna (Fitzherbert et al. 2008; Koh and Wilcove, 2008; Brühl and Eltz, 2009; Wilcove and Koh 2010). Rhis is different from oil palm which is almost non-recoverable and threatens the fauna of native species in the region. Meijaard and Sheild (2013) in their study in Indonesia also identified similar results, namely that oil palm has caused the loss of endemic fauna, including Sunbears, Orangutan, Sumatran tigers, and elephants. Therefore, in the conversion of just one hectare of forest can result in significant loss of fauna diversity.

The reduction in native fauna, the clearing of oil palm plantations by burning forests has also increased greenhouse gas emissions in the form of carbon dioxide (Sheil et al., 2009; Carlson et al., 2012). The increase in carbon dioxide as a result of burning forest land places Indonesia as the country with the third largest greenhouse gas contributor in the world (Sundaraja et al, 2020). The effects of burning forests such as peatlands have increased haze and have increased respiratory health risks in Southeast Asia (Islam et al, 2016). The world's oil palm producing countries are urged to reduce deforestation by reducing the footprint of oil palm lands. Consumers in European countries have intensified policies against deforestation caused by oil palm in the Asian region and have accelerated interventions since 1990 (Pye et al., 2012). The impact of this intervention was the issuance of a standard, namely the Roundtable on Sustainable Palm Oil (RSPO) in 2004, with the aim of supporting sustainable palm oil (RSPO, 2018).

In 2013, ambitious declarations for eliminating deforestation had become the main goal. European countries, through the 2015 Amsterdam declaration agreement committed to ensure that all palm oil traded by 2020 must meet certification. Countries such as Belgium, Denmark, France, Germany, Italy, Norway, the Netherlands, Sweden, and the United Kingdom (UK) began implementing palm oil certification in 2020. The Dutch oil and grease industry (MVO) together with the Institute for Sustainable Trade (IDH) established the European Sustainable Palm Oil Project (ESPO) to support 100 percent of sustainable palm oil sources (European Sustainable Palm Oil (ESPO) 2017). Norway became the first country to implement a zero-deforestation commitment for all forms of public procurement activities (Gaworecki, 2016). In 2017, the European Parliament conducted an experiment to impose stricter provisions on palm oil imported by the European market, which included eliminating palm oil as a component of biofuels (European Parliament, 2017; Pacheco et al. 2020).

Despite the aggressiveness of environmentalists to call for environmental damage (FoE, 2005; Greenpeace, 2007; Koh et al., 2010), the development of oil palm continues to expand in tropical areas. Social, economic and ecological problems are the main factors shaping development of oil palm in the tropics. There are at least three motives in the development of oil palm in tropical areas (Wilcove and Koh, 2010); First, oil palm is one of the most profitable crops in the world. Countries with the largest oil palm plantations, such as Indonesia, increase the amount of cultivated land to increase income, which has become a motivation to get obtain higher state revenue. Second, the need for palm oil is used in a wide variety of products, making a boycott of palm oil products is unlikely to succeed. Third, the largest markets for palm oil, namely China and India, have not shown a decrease in consumption of palm oil, making it impossible to boycott palm oil products. This kind of situation is complex because, oil palm plantations has been attributed to increasing overall welfare (Rist et al., 2010). Nevertheless, the ongoing encroachment of land to expand oil palm cultivation has caused local communities to lose their use of forest resources.

Considering these negative impacts and benefits, evaluating the efficiency of land use is a way to reduce the rate of deforestation. Evaluation of land use efficiency aims to measure land usage in an area. Traditionally, measuring the level of land use efficiency can be done by using an economic approach, one of which is the stochastic frontier analysis (SFA) approach. The stochastic frontier approach in analyzing land use efficiency has been widely used. Polasky et al., (2008) applied a frontier approach to identify land use policies that maximize production level to support biodiversity 
and economic benefits. Ferreira and Feres, (2020) conducted a similar method in analyzing the efficiency of land use using the stochastic frontier in Brazilian Amazon forests in 2006.

Overall, the purpose of this study is to measure the level of efficiency of land usage in oil palm plantations using the input distance function approach complemented by estimate of the stochastic frontier. Discussions of the social and economic characteristics of smallholders will provide a better explanation of how to increase land efficiency for Indonesian oil palm plantations. This study provides evidence to stakeholders to improve the efficiency of oil palm land use. The paper proceeds as follows; Section 2 covers key aspects of land use efficiency, section 3 present the theoretical models, section 4 presents data and estimation techniques, section 5 focuses on the findings and section 6 provides overarching conclusions.

\section{Literature Review}

Land usage efficiency is a dynamic and complex concept. The indicator for measuring land efficiency of an area is determined by the interaction of physical, socio-economic, and technological factors. The concept of efficiency of agricultural land use is just as complex as the concept of quantification. However, several attempts have been made to simplify measurements so that it is easy to understand, model, ensure precision, and meet the overall objectives (Reddy and Ramanaiah, 1985).

Efficiency is generally defined as the relationship between input and output. However, the general definition of measuring the efficiency of land usage is not defined by a standard, nor are there standard measurement methods to assess land usage efficiency. Measuring land usage efficiency is an important indicator that reflects the rational conditions of various inputs in the land use process (Lie et al., 2018) and also reflects the conditions of land that are cultivated in the agricultural production process (Reddy and Ramanaiah, 1985). There have been many studies conducted on the evaluation of land use at different time scales and spatial scales. Some of these studies include: Zhou's (2012) analysis of land usage efficiency and food security in Henan province using statistical data of Henan province from 1999-2008. The data variables used were the use of fertilizers per hectare, multiple crop indexes, the level of urbanization, per capita income, water resources, rainfall and machine use on the output produced. Analyzed using a multiple linear regression model approach, Lie et al. (2018) developed a theoretical framework for evaluating the efficiency of land use and adopted the entropy value method, and then analyzed the data using the analysis tools of the Stochastic Frontier Analysis (SFA) and Development Analysis (DEA) methods. Ferreira and Feres (2020) analyzed the efficiency of land usage in the Brazilian Amazon using 2006 agricultural census data, applying a stochastic frontier approach to analyze excessive land usage. Wang and Li (2014) also conducted an analysis of the stochastic frontier production function to estimate land usage efficiency using panel data from 281 cities in China from 2001 to 2011. Literature studies reveal that efficiency analysis is considered important in determining the performance of land parcels. Overall, the literature study of stochastic frontier approaches requires new, more specific approaches to measure land use efficiency. Our study develops an input distance function approach to measure the level of land use efficiency more effectively.

The input distance function approach to evaluate changes to agriculture is nothing new. An important tool for analyzing the efficiency of land usage for oil palm is the stochastic frontier proposed by Aigner et al. (1977) and the distance function approach was first introduced by Shephard (1970). Over the years, the input distance function approach and SFA have been widely used in various fields. In agriculture, Irz and Thirtle (2004) analyzed the productivity performance of vulnerable Botswana agriculture from 1979 to 1996, using two inputs and six outputs with the stochastic tranlog (TL) input distance functions. Rasmussen (2010) analyzed the efficiency scale of livestock in the Danish region by using the Input distance function approach with stochastic frontier 
analysis. Nguyen (2017) analyzes the efficiency of rural rice farming in Vietnam using the input distance function approach.

However, the measurement of land use efficiency using the input distance function approach is less of a concern. Overall, the objective of our study is to analyze the efficiency of land usage using the input distance function approach and to estimate it using the SFA analysis tool. The input distance function approach has the advantage of accommodating multiple outputs and this is different from the usual production function, which is constrained to limited output variables (Coelli et al. 2003). Furthermore, land use efficiency studies using the input distance approach and SFA have never been carried out. Thus, the aim of our study is to fill a gap in the literature and provide input to the government on the efficiency of land usage in smallholder oil palm plantations.

\section{Methodology}

To measure land usage efficiency from the point of view of the production function we use the input distance Shephard function of the land usage sub-vector. The input distance function was first introduced by Shephard (1970). In simple terms, the input distance function is a model that requires a specified input, $L\left(y^{0}\right)$ (Irz and Hadley, 2003). Following the Sub-distance function concept developed by Färe and Primont (1995) and Zhou (2012). Mathematically, the input distance function can be defined by:

$$
D_{i}(y, l a)=\sup \{\lambda>0:(l a / \lambda) \leqq 1\}
$$

Equation (1) in the input distance function proportionally measures the level of use of the input vector la which can be reduced to produce an output of $y$ with a technological factor at a certain time t. Each combination $(l a, y)$ has a technology set, assuming the value of the input distance function has a value of less than one, if it has a value of one then it is considered a technical efficiency. Farrell (1975) in the analysis of input distance functions has a well-known reciprocity of efficiency techniques. The return function from the input distance function can be defined as the land use efficiency index (LEU):

$$
E P L=1 / D_{L a}(x ; l a, y)
$$

Equation (2) represents a land usage index level where $0<L E U<1$ means that if it is less than one then it is assumed to be the input distance function, if it is more than zero, the better. The curve of Figure 1 provides an isoquant illustration of the production function. In Figure 1, the production function illustrates the input $L a$ as land and $Y$ as output, and it is assumed that other input factors are considered constant.

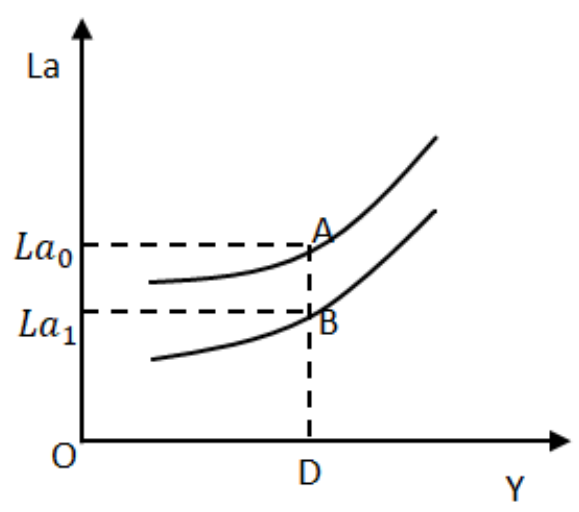

Figure 1. Illustration chart of land efficiency 
The starting point of the isoquant production function is rated $A$ with value $\left(L a_{0}\right)$. The Isoquant of the production function is necessary to reduce the level of land input used, namely point $A\left(L a_{0}\right)$ to point $B\left(\operatorname{La}_{1} / D_{\mathrm{La}}(x ; / a, y)\right.$. Figure 1 highlights the distance $A$ to $B$ and illustrates the value of the input distance function which is the same as the DA/DB ratio and the inverse value is the value of the resulting LUE (Zhou, 2012).

The value of the input distance function cannot be used directly as an estimate. Following the model used by Irz and Hedley (2003) and Zhou et al (2012), implementing the logarithmic function in the input distance function, mathematically, can be notated by;

$$
\ln D_{i}(x ; \operatorname{la}, y)=\lambda+\ln D_{i}(x ; l a, y)
$$

The input distance function has a homogeneous linear assumption (Lovell et al., 1994) which can be mathematically expressed by:

$$
\ln D_{i}(x ; l a, y)=\lambda+\ln D_{i}\left(x ; l a / l a_{1}, y\right) \forall \lambda>0
$$

The implementation of the application of the input distance function in measuring land efficiency requires a more specific function. Deterministic model application is considered as the right choice in applying the input distance function by following the stochastic frontier analysis. The stochastic frontier analysis has two components, which are the $v_{i}$ variable and the $u_{i}$ variable. $v_{i}$ is a special component that captures errors or interruptions in measurement. $u_{i}$ is an inefficiency variable that has non-negative assumptions. Mathematically, it can be represented by;

$$
\ln D_{i}(x ; l a, y)=-v_{i}+u_{i}
$$

The combination of equations (4) and (5) can be mathematically notated by;

$$
D(1 / l a)=\lambda D\left(x ; l a_{i}, y, \beta\right) \exp \left(v_{i}-u_{i}\right) i=1,2, \ldots, N .
$$

Equation (6) has an input distance function parameter with random distribution assumptions, so it can be estimated using the maximum likelihood method that has been widely used in the stochastic frontier (Coelli, Rao and Battese, 1998). In equation (6) the notation $v_{i}$ is the random error term $v_{i}-i . i . d . N\left(0, \sigma_{v}^{2}\right)$ and $u_{i}$ is the set of technical inefficiency terms $u_{i}-N\left(\mu_{i}, \sigma_{u}^{2}\right)^{+}, i=$ $1,2, \ldots, N$.

Equation (6) is theoretically based on the stochastic frontier proposed by Aigner et al. (1977), emperically equation (6) can be expressed by:

$$
\begin{aligned}
D\left(\frac{1}{l a}\right)=\beta_{0}+ & \sum_{n=2}^{7} \beta_{n} \ln x_{n}+\frac{1}{2} \sum_{n=2}^{7} \sum_{k=2}^{7} \beta_{n n} \ln x_{n} \ln x_{n}+\sum_{m=1}^{1} \alpha_{m} \ln y_{m}+\frac{1}{2} \sum_{m=1}^{1} \sum_{m=1}^{1} \beta_{m m} \ln y_{m} \ln y_{m} \\
& +\sum_{n=2}^{7} \sum_{m=1}^{1} \gamma_{n m} \ln x_{n} \ln y_{m}+v_{i}-u_{i}
\end{aligned}
$$

Where $y$ represents the output and $x$ represents the input vector used. $v i$ represents a random error and ui is a one-sided error which has been described in equation (6) which presents the characteristics of inefficiency variables on oil palm plantations.

The coefficient in equation (7) will be estimated using the maximum-likelihood method that has been done previously by Battese and Coelli (1995). Maximum-likelihood can be written in terms of variant parameters: $\sigma_{s}^{2}=\sigma_{v}^{2}+\sigma^{2}$ and $\gamma=\sigma_{u}^{2} / \sigma^{2}, 0<\gamma<1$. The production function model will be realized if the value $y=0$ and the variable $z$ is entered directly into the production function. This 
shows that the standard regression to estimate the production function is in accordance with the data. However, the application of the SFA model will be fulfilled if $\gamma$ approaches one.

\section{Data}

The data in this study uses the 2013 agricultural census data (household survey (plantation business 2014) which is shown in Table 1. The data includes 7,139 observations and were obtained from the Central Statistics Agency (BPS). This study uses one output and multiple inputs consisting of Output (y). The output in this study is calculated based on the total number of self-harvested plants plus the by-product, cut cropping and bonded value which is calculated based on the value of thousands of rupiah. Labor (tk), is calculated based on the total number of men and women workers. Fertilizer (pu) is measured by adding up all types of fertilizers used, namely urea, TSP / SP36, ZA, KCL, NPK, organic fertilizers (manure / compost) and others, measured in kilograms. Pesticides (ps) is measured by adding up the total solid and liquid pesticides with a size value of thousands of rupiah. Trees (po) aer the total plants calculated based on plant conditions, namely immature plants (TBM), mature plants (TM) and the plants that do not produce (TTM), namely those that are old and damaged. Land area (la) is the area of land per hectare in oil palm plantations.

Table 1. A Statistical Summary of Variables

\begin{tabular}{lllllll}
\hline Variable & Parameter & Obs & Average & DS & Min & Max \\
\hline Iny(Output) & In(Thousands of Rupiah) & 7139 & 10.240 & 1.1421 & 3.4965 & 14.551 \\
Intr(Tree) & In(Tree trunk) & 7139 & 5.3674 & 1.2640 & 0.6931 & 9.3101 \\
Infr(Fertilizer) & In(Thousands of Rupiah) & 7139 & 6.7915 & 1.2930 & 1.0986 & 11.581 \\
Inps(Pesticide) & In(Thousands of Rupiah) & 7139 & 6.3350 & 1.0492 & 1.0986 & 11.587 \\
Inl(Workforce) & In(Amount of workforce) & 7139 & 0.9631 & 0.6180 & 0 & 5.1239 \\
Inla(Land area) & In(hectare) & 7139 & 0.7229 & 1.0909 & 0.0005 & 222.22 \\
\hline
\end{tabular}

Note: average: arithmetic mean; DS: Deviation standard; Min: minimum Max: maximum; the estimates of $y$, $t r, f r, p s$, I and la are natural logarithms.

\section{Results}

Estimation of equation (7) has two random variables, which are vi and ui. ui assumes halfnormal, truncated normal distribution, exponential distribution, and gamma distribution. In this study we use the half-normal assumption and the estimation of equation (7) uses the maximum likelihood method shown in Table 2. Table 2 are the results of the estimation of the translog model function in equation (7), which has no economic meaning. Therefore, in this study we reduce the elasticity of land to output and input (trees, fertilizers, pesticides, and labor). Land elasticity is obtained by taking the partial order derivative of the first derivative in the model. Each variable used was evaluated at a specific variable value by calculating at the full sample mean.

Table 3 presents the estimated results of land elasticity respective to each input and output used. Elasticity serves to provide an idea of how much the change in the percentage of land increases when the percentage change in input and output increases. The average land elasticity to trees had the highest value, which is 0.8641 , while the land elasticity to output is 0.0438 . This indicates that the increase in land area is more because of the increase in the number of trees, while the resulting output is smaller. This is reasonable if we view the yield of smallholder oil palm productivity as lower than the productivity of the company and the government. Fertilizer input has an average value of 0.0170 , while pesticides are rated higher at 0.0675 and labor is at 0.0438 . Smallholders do more to eradicate pests which is one of the problems in oil palm plants. This shows that the use of fertilizers is less than pesticides, smallholders face more crop pests which reduce the productivity of oil palm plantations. The use of labor in the oil palm management process by smallholders involves more family members or close relatives so that it does not require much labor. 
Table 2 Estimation of Maximum-Likehood Stochastic Production Frontier

\begin{tabular}{|c|c|c|c|c|}
\hline Variable & Coefficient & $\begin{array}{c}\text { Coefficient of } \\
\text { Estimation }\end{array}$ & Std-error & t-statistic \\
\hline Constant & $\beta_{0}$ & $5.9362 * * *$ & 0.3903 & 15.2102 \\
\hline $\operatorname{Tr}$ & $\beta_{t r}$ & $-0.6977 * * *$ & 0.1043 & -6.6872 \\
\hline$F r$ & $\beta_{f r}$ & 0.0665 & 0.0699 & 0.9518 \\
\hline Ps & $\beta_{p s}$ & -0.0409 & 0.0768 & -0.5331 \\
\hline$L$ & $\beta_{l}$ & $0.5220 * * *$ & 0.1145 & 4.5588 \\
\hline$Y$ & $\beta_{y}$ & $-0.3527 * * *$ & 0.0770 & -4.5830 \\
\hline$t r^{2}$ & $\beta_{\text {trtr }}$ & $0.1103^{* * *}$ & 0.0249 & 4.4344 \\
\hline$f r^{2}$ & $\beta_{f r f r}$ & 0.0108 & 0.0090 & 1.2050 \\
\hline$p s^{2}$ & $\beta_{p s p s}$ & $0.0152 *$ & 0.0102 & 1.4805 \\
\hline $1^{2}$ & $\beta_{l l}$ & $0.0726 * * *$ & 0.0217 & 3.3514 \\
\hline$y^{2}$ & $\beta_{y y}$ & $0.0795 * * *$ & 0.0110 & 7.2061 \\
\hline $\operatorname{Trfr}$ & $\beta_{t r f r}$ & 0.0038 & 0.0131 & 0.2901 \\
\hline Trps & $\beta_{\text {trps }}$ & $-0.0454 * * *$ & 0.0140 & -3.2449 \\
\hline $\operatorname{Trl}$ & $\beta_{t r l}$ & 0.0109 & 0.0200 & 0.5479 \\
\hline Try & $\beta_{\text {try }}$ & $-0.0651 * * *$ & 0.0151 & -4.3266 \\
\hline Frps & $\beta_{\text {frps }}$ & -0.0056 & 0.0086 & -0.6553 \\
\hline $\mathrm{Frl}$ & $\beta_{f r l}$ & $0.0373 * * *$ & 0.0134 & 2.7865 \\
\hline Fry & $\beta_{\text {fry }}$ & $-0.0165^{* *}$ & 0.0092 & -1.7858 \\
\hline Psl & $\beta_{p s l}$ & 0.0169 & 0.0145 & 1.1690 \\
\hline Psy & $\beta_{p s y}$ & $0.0208 * *$ & 0.0103 & 2.0195 \\
\hline Ly & $\beta_{l y}$ & $-0.1037 * * *$ & 0.0148 & -6.9874 \\
\hline Sigma-squared & $\sigma^{2}$ & $0.7881 * * *$ & 0.0151 & 52.199 \\
\hline Gamma & $\gamma$ & $0.8890 * * *$ & 0.0035 & 253.71 \\
\hline Likehood Log Function & & -6514 & & \\
\hline One-side L.R Error Test & & 2435 & & \\
\hline
\end{tabular}

Note: the level of significance used is up to $\alpha=10$ percent. ${ }^{* *}$ significant 1 percent ${ }^{* *}$ Significant at 5 percent and ${ }^{*}$ Significant at 10 percent.

Table 3 Elasticity of Output with Respect to Each Input

\begin{tabular}{lc}
\hline Variable & Elasticity \\
\hline Tree Elasticity $\left(\varepsilon_{\mathrm{tr}}\right)$ & 0.8641 \\
Fertilizer Elasticity $\left(\varepsilon_{\mathrm{fz}}\right)$ & 0.0170 \\
Pesticide Elasticity $\left(\varepsilon_{\mathrm{ps}}\right)$ & 0.0675 \\
Labor Elasticity $\left(\varepsilon_{\mathrm{l}}\right)$ & 0.0345 \\
Land Elasticity $\left(\varepsilon_{\mathrm{la}}\right)$ & 0.0438 \\
Total $(\varepsilon)$ & $\mathbf{1 . 0 2 6 9}$ \\
\hline
\end{tabular}

Note:total elasticity is $\varepsilon=\varepsilon_{\mathrm{tr}}+\varepsilon_{\mathrm{fz}}+\varepsilon_{\mathrm{ps}}+\varepsilon_{\mathrm{l}}+\varepsilon_{\mathrm{la}}$

The calculation of land use efficiency in each province is shown in Table 4. Furthermore, Table 4 can be interpreted as follows; first, the overall average of smallholder oil palm plantations from the 17 provinces analyzed is below one, meaning that the overall average of the analyzed provinces experiences land inefficiency. The average land efficiency is in the value range 0.1 to 0.7 or is at a medium efficiency level. This finding is in line with studies conducted by Hoffmann et al., (2015) and Varkey et al., (2018) who found land use factors in Indonesian oil palm plantations experiencing inefficiency in land use due to concerns about excessive coconut land use. This situation is concerning because Indonesia's oil palm lands are located in primary forest and peat forest (Wicke 
et al., 2011). Second, the provinces with the highest scores are South Sumatra (0.715), Central Kalimantan (0.702), West Sulawesi (0.701) and the lowest from the bottom are Lampung (0.620), Jambi (0.633), and Bengkulu (0.653). Third, Sumatra and Kalimantan are the largest centers for palm oil producers but have relatively low levels of land efficiency. The opportunities for achieving a higher level of efficiency can still be improved. Figure 2 shows the number of plants planted, young and already productive ones that have the potential to increase even higher, and have the potential to maximize the available land area.

Table 4 Estimation Results of Land Efficiency Per-Province

\begin{tabular}{|c|c|c|c|c|c|c|}
\hline \multirow{2}{*}{ Province } & \multirow{2}{*}{$\begin{array}{l}\text { Average land } \\
\text { efficiency }\end{array}$} & \multirow{2}{*}{$\begin{array}{l}\text { Number of } \\
\text { plantations }\end{array}$} & \multirow{2}{*}{$\begin{array}{c}\text { Total } \\
\text { area (ha) }\end{array}$} & \multicolumn{3}{|c|}{ Level of land efficiency } \\
\hline & & & & 1 & $0.9-0.6$ & $0.5-0.1$ \\
\hline South Sumatera & 0.715 & 431 & 1575.5 & 14 & 372 & 45 \\
\hline Central Kalimantan & 0.702 & 511 & 3470 & 0 & 465 & 46 \\
\hline West Sulawesi & 0.701 & 455 & 1265.5 & 0 & 428 & 27 \\
\hline Riau & 0.698 & 1446 & 4601.5 & 0 & 1.357 & 89 \\
\hline Aceh & 0.693 & 525 & 1400.5 & 1 & 443 & 81 \\
\hline Bangka Belitung & 0.693 & 215 & 866.7 & 1 & 179 & 35 \\
\hline North Sumatera & 0.687 & 925 & 7538 & 1 & 822 & 102 \\
\hline West Kalimantan & 0.686 & 302 & 2939.4 & 2 & 255 & 45 \\
\hline South Kalimantan & 0.683 & 100 & 275.4 & 0 & 81 & 19 \\
\hline West Sumatera & 0.682 & 285 & 669 & 0 & 240 & 45 \\
\hline Central Sulawesi & 0.677 & 75 & 155.8 & 0 & 67 & 8 \\
\hline East Kalimantan & 0.677 & 453 & 2873.1 & 0 & 390 & 63 \\
\hline South Sulawesi & 0.669 & 76 & 1330.3 & 0 & 54 & 22 \\
\hline Bengkulu & 0.653 & 473 & 1739.3 & 3 & 318 & 152 \\
\hline Jambi & 0.633 & 649 & 21688 & 0 & 510 & 139 \\
\hline Lampung & 0.620 & 218 & 2861.1 & 0 & 165 & 53 \\
\hline
\end{tabular}

Note; average land efficiency: the average value of land efficiency in each region; number of plantations: number of plantations analyzed; total area: the total area in each area analyzed by hectare (ha); land efficiency level: the level of value scores obtained by each smallholders land are then classified based on the acquisition of a score score

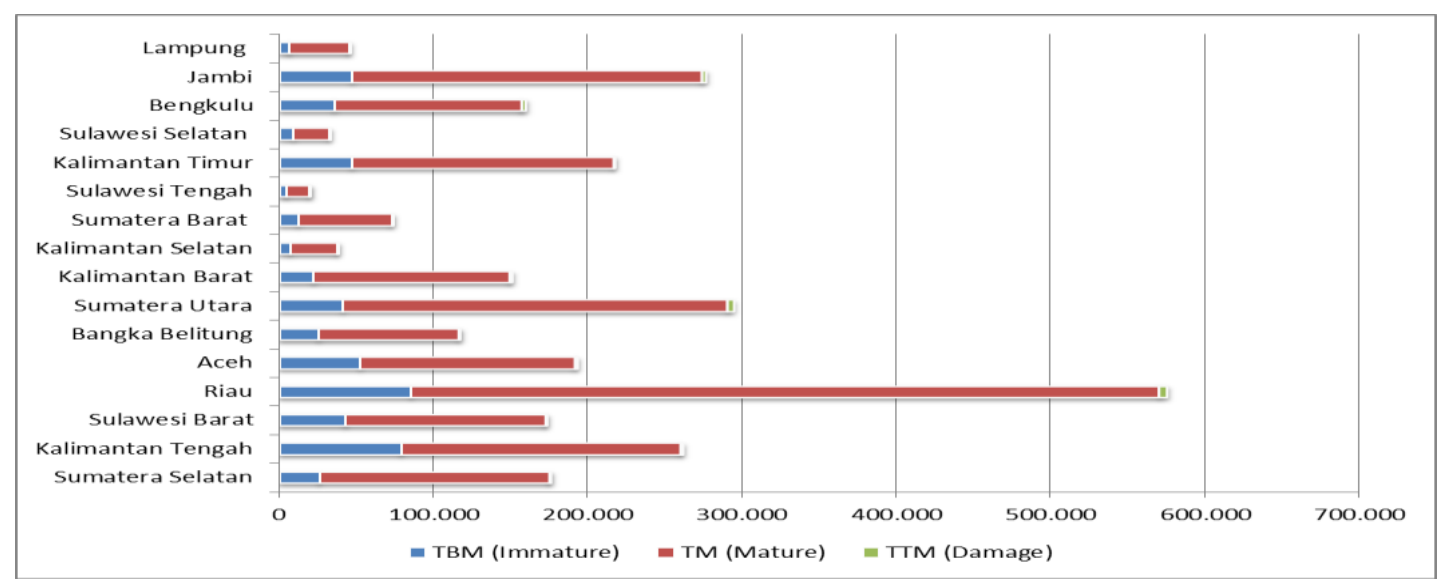

Figure 2. Number of trees in each province. Source: primary data analysis (2013)

The land efficiency in each area is measured by value per hectare. The results of BPS data reported that per-plot productivity levels tended to remain in the range of 3 to 4 tons. In research 
conducted by several studies, the comparison of smallholder oil palm productivity is below plantation standards (Corley and Tinker, 2003; Vermeulen and Goad, 2006; Euler et al., 2016). To meet the increasing demand for palm oil, the government has granted permits for oil palm plantations through the Minister of Agriculture Regulation number 98 of 2013, which was later changed to the Minister of Agriculture Regulation number 21 of 2017, causing widespread deforestation. Susanti and Maryudi (2016) divided 3 phases that encourage forest deforestation in their research: first, the expansion phase is driven by increasing global palm oil demand; second, the urgency of encouraging expansion to find alternative sources of income to replace income from forestry sources; and third, the expansion of oil palm land is accelerated by the implementation of government decentralization.

With the high demand and support from the government to continue to increase its production, palm oil has become one of the largest contributors to deforestation. From 2009 to 2013, oil palm has played a role in forest deforestation reaching 515 thousand hectares, of which Kalimantan is the largest contributor to reach 327.5 thousand hectares in concession lands (FWI, 2014). In 2013-2017, oil palm played a role in deforestation reaching 586.3 thousand hectares, whereby Kalimantan was the largest contributor reaching 313.6 thousand hectares in concession areas ${ }^{1}$. One of the cheapest and most effective methods of deforestation in clearing oil palm plantations is by burning forests. This shows the direct role of oil palm in forest deforestation in Indonesia. Data on the distribution of hotspots for 2013-2017 shows that more than 656 thousand hotspots have been detected with a confidence level of above 70 percent throughout Indonesia with $44 \%$ (286,701 hotspots) of which are in concession forests. Out of the 286.70 thousand hotspots, nearly $80 \%$ are in concessions of Industrial Plantation Forest (IPF) with 121.1 thousand hotspots and oil palm with 109.2 thousand hotspots (FWI, 2018).

Deforestation by burning forests has a negative impact on life aspects. Forest fire cases in 2015 are predicted to have an impact on premature death rates in three countries, namely Indonesia with 91,600 deaths, Malaysia with 6,500 deaths and Singapore with 2,200 deaths. In 2006, oil palm contributed $11 \%$ of hotspots in the Sumatra region and $32 \%$ in the Kalimantan region, and in 2015, it contributed $5 \%$ in the Sumatra region and $20 \%$ in the Kalimantan region (Koplitz et al., 2016). Research between 1990-2010, showed there had been deforestation for oil palm plantations with an emission contribution of $0.020-0.024 \mathrm{GtC}^{-1}$. Saharjo et al., (2012) found in their research that within forest and land fires from 2000 to 2009, the change for oil palm by burning had caused emissions to reach 801,764 tons with the highest value in 2005 reaching 459,427 tons. Meanwhile, conversion of peat land from swamp forest in 2005 reached emissions of 80,851 tons and primary swamp forest in 2009 with emissions of 180,531 tons. Agarwal et al., (2020) found in their research that there has been an increase in the use of water and electricity due to an increase in pollution from Indonesia's forest fires.

\footnotetext{
${ }^{1}$ Concession is the act of granting permits or land by an illegal government, company, individual or entity. Concessions, among others, are applied to clearing mines, plantation land and forest clearing.
} 


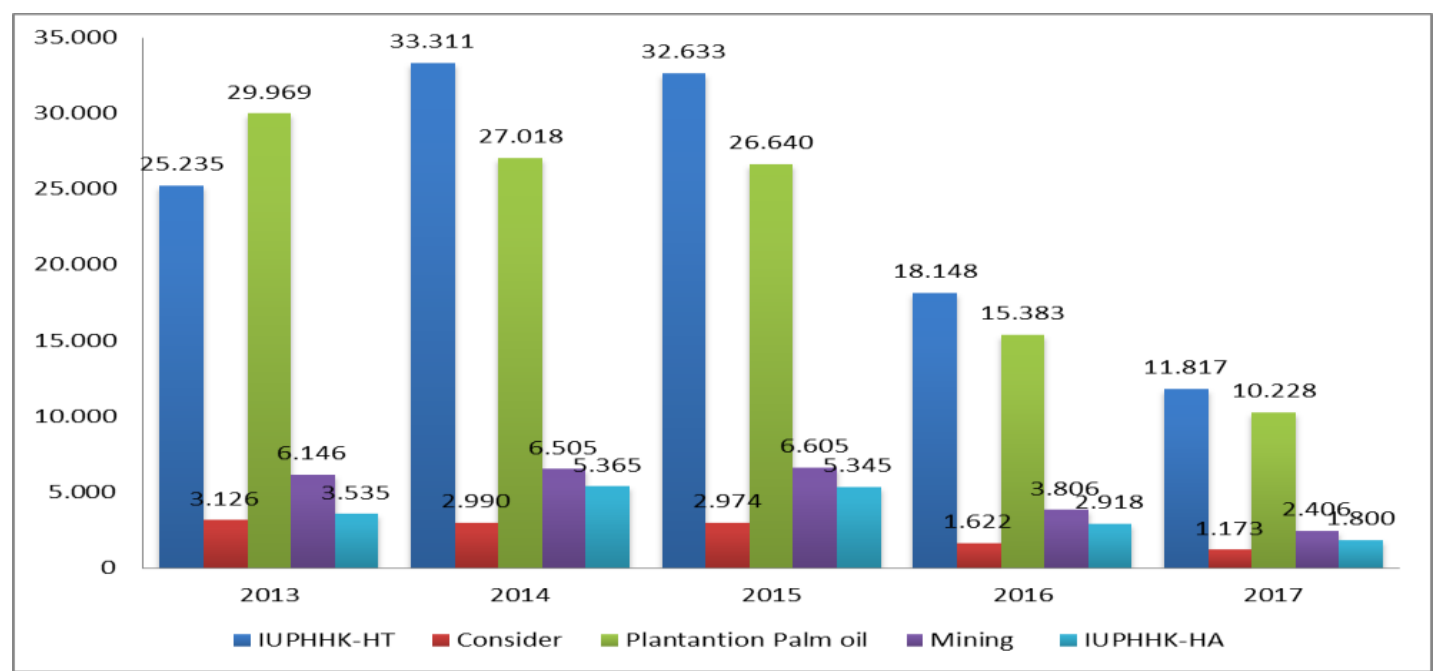

Figure 3. Distribution of hotspots ${ }^{2}$ in Indonesia 2013-2017 within the concession areas. Source: FWI, 2018

The province of Riau is one example of an area where the growth of deforestation for oil palm is quite large. The estimation result of land efficiency in Riau province on average is 0.6978 , which means that it has relatively low land efficiency. This is not comparable to the considerable deforestation in Riau province, whereby the economic shift took place from an area dominated by forest and turned into the largest oil palm producing area. For almost 25 years, the province of Riau has lost 4 million hectares or close to $65 \%$ of the total area of Riau province. Over the past 25 years from 1982 to $2008,29 \%$ of deforestation was caused by oil palm, $24 \%$ by the timber industry, and $17 \%$ by other factors. In a study conducted by Tesso Nilo-Bukit Tiga puluh-Kampar, the total of deforestation reached $55 \%$, with $95 \%$ deforestation in areas with very good forest conditions. Natural forests that are still in very good condition have turned into oil palm plantations with a forest degradation rate of up to 85 percent. From 1970 to 2007, deforestation in Riau province had contributed 3.66 gigatons $(\mathrm{Gt})$ of $\mathrm{CO}_{2}$. This has made Indonesia as the country with the largest carbon dioxide contributor. Oil palm plantations have also played a role in increasing deforestation by $0.24 \mathrm{Gt} \mathrm{CO}_{2}$. The process of deforestation, forest degradation, and forest fires in Riau is an average contributor of $\mathrm{CO}_{2}$ of $0.22 \mathrm{Gt}$. This is equivalent to $58 \%$ of Australia's $\mathrm{CO}_{2}$ emissions in 2005 and $79 \%$ of total energy sector emissions in 2004 (WWF Indonesia, 2008).

The findings of the analysis of land use efficiency and environmental impacts of deforestation need to be addressed by encouraging land intensification and promoting sustainable oil palm plantations. The intensification of land for oil palm plantations plays an important role in supporting efficient land use and reducing deforestation. The sustainable plantation aspect is a continuous intensification process, which increases yields without causing environmental impacts and without increasing the amount of land used for plantations (The Royal Society, 2009). Intensification has the aim of increasing productivity without increasing the amount of land area being used for plantation so that the demand for agricultural products such as oil palm can be met with a limited amount of land (Fairhurst and McLaughlin, 2009; Woittiez, 2019). However, intensification must also be done correctly and appropriately. Several influences such as technological factors and the socio-political role of the state play an important role in the land intensification process. Varkkey et al., (2018) found that the Indonesian government has no commitment to reduce the rate of deforestation due

\footnotetext{
2 Note (Figure 3): hotspot is an indicator of a forest fire detected in a location that has a relatively high temperature if compared to the ambient temperature (Article 1 number 9 Minister of Forestry Regulation No.P 12/Pmenhut-2009); calculated by unit of thousand hotspots .
} 
to oil palm, and regional political influence plays a role in the increasingly widespread process of deforestation. The government's commitment to temporarily stop deforestation has not clearly committed to reducing land expansion.

\section{Conclusion}

This study aimed to evaluate the efficiency of land use for smallholder oil palm plantations in each province in Indonesia. This study uses an input distance function approach, and then it is estimated by using stochastic frontier analysis to determine the level of land efficiency in each area. The study results show that on average, smallholder oil palm plantations are at a value of 0.781 . If we judge it based on the determined value, on average, smallholder oil palm plantations experience land inefficiency. The results of the mapping of the three regions with the highest efficiency are South Sumatra (0.715), Central Kalimantan (0.702), and West Sulawesi (0.701) and the three lowest from the bottom are Lampung (0.620), Jambi (0.633), and Bengkulu (0.653). Based on the elasticity level of the use of each input used, land expansion is more due to the number of trees planted, while the resulting output is smaller.

Our findings do not match the environmental impact. Several records of deforestation continue to take place and expand from year to year. The narrative of oil palm in the context of large profits, the development of countries, regions, poverty alleviation and the high global demand for oil palm have driven a massive expansion into forests. The effect is that more than 12.3 million hectares of forest land have been lost, replaced by oil palm plantations. On average, deforestation of Indonesia's oil palm forests is in the areas of primary forest and peat forest. Some of the environmental impacts experienced as a result of land clearing, include the following. First, there has been a significant increase in carbon dioxide emitted, which occurs due to forest burning in dense forest areas, especially in peat forest areas that have a higher risk of producing carbon dioxide. Studies conducted by Germer and Saurban (2008) and Achten and Verchot (2011) found that an increase in carbon dioxide and the length of time it takes to replace carbon dioxide due to expansion of oil palm land. Second, the health impact which affects the risk of premature death to citizens and people in neighboring countries are affected by increased haze due to clearing land for oil palm by burning forests (Koplitz et al., 2016).

Land intensification is one of the options to reduce the rate of deforestation while continuing to maximize production levels. There are several ways to increase land intensification. Byerlee et al. (2014) conducted several study combinations to encourage intensification. First, lowering market prices for technology-based intensification of production inputs can support the production function, which is defined by reducing production costs per unit of output. Second, spatial shifts in production will affect demand for land through more efficient innovations, which can increase exports. Third, through the labor market, intensification in lowlands will attract labor in the highlands, and through faster agricultural economic growth, the overall economy will grow as a result of agricultural wages and demand for oil palm (Indonesia's regional economy). Apart from the production mechanism, the intensification of land for oil palm plantations can be done by selecting areas that have the potential for good land conditions, replanting oil palm plants, providing facilities and infrastructure, developing priority plantation areas and cooperating with the private sector and developing technology. Land intensification can be successful if all stakeholders jointly commit to promoting sustainable palm oil to reduce excess deforestation. Our findings can become a reference for governments, companies, and smallholders to take certain steps in the process of better management of the palm oil sector.

\section{Conflicts of interest}


Author declares no conflict of interest

\section{References}

Achten, W. M., \& Verchot, L. V. (2011). Implications of Biodiesel-Induced Land-Use Changes for $\mathrm{CO}_{2}$ Emissions: Case Studies in Tropical America, Africa, and Southeast Asia. Ecology and Society, 16(4). http://dx.doi.org/10.5751/ES-04403-160414

Agarwal, S., Sing, T. F., \& Yang, Y. (2020). The impact of transboundary haze pollution on household $\begin{array}{lll}\text { utilities } & \text { consumption. Energy } & \text { Economics, 85, }\end{array}$ https://doi.org/10.1016/j.eneco.2019.104591

Aigner, D., Lovell, C. K., \& Schmidt, P. (1977). Formulation and estimation of stochastic frontier production function models. Journal of econometrics, 6(1), 21-37. https://doi.org/10.2307/2522871

BPS. (2018). Statistik Kelapa Sawit Indonesia 2017.

Battese, G. E., \& Coelli, T. J. (1995). A model for technical inefficiency effects in a stochastic frontier production function for panel data. Empirical economics, 20(2), 325-332.

Brühl, C. A., \& Eltz, T. (2010). Fuelling the biodiversity crisis: species loss of ground-dwelling forest ants in oil palm plantations in Sabah, Malaysia (Borneo). Biodiversity and Conservation, 19(2), 519-529. DOI 10.1007/s10531-009-9596-4.

Byerlee, D., Stevenson, J., \& Villoria, N. (2014). Does intensification slow crop land expansion or encourage deforestation?. Global food security, 3(2), 92-98. https://doi.org/10.1016/j.gfs.2014.04.001

Carlson, K. M., Curran, L. M., Asner, G. P., Pittman, A. M., Trigg, S. N., \& Adeney, J. M. (2013). Carbon emissions from forest conversion by Kalimantan oil palm plantations. Nature Climate Change, 3(3), 283-287. https://doi.org/10.1038/nclimate1702

Coelli, T., Singh, S., \& Fleming, E. (2003). An input distance function approach to the measurement of technical and allocative efficiency: With application to Indian dairy processing plants. Unpublished manuscript.

Coelli, T. J., Rao, D. P., O’Donnell, C. J., \& Battese, G. E. (1998). An introduction to productivity and efficiency analysis. Springer Science: New York.

Corley, R. H. V., and P. B. Tinker. (2003). The oil palm. Fourth edition. Blackwell Science, Oxford, UK.

Euler, M., Hoffmann, M. P., Fathoni, Z., \& Schwarze, S. (2016). Exploring yield gaps in smallholder oil palm production systems in eastern Sumatra, Indonesia. Agricultural Systems, 146,111-119. . https://doi.org/10.1016/j.agsy. 2016.04.007

European Parliament (2017) Palm Oil and Deforestation of Rainforests. European Parliament Resolution of 4 April 2017 on Palm Oil and Deforestation of Rainforests (2016/2222(INI)). 2016 edn. European Parliament, Brussels, Belgium.

Fairhurst, T., \& McLaughlin, D. (2009). Sustainable oil palm development on degraded land in Kalimantan. World Wildlife Wund, Washington, DC. http://www.academia.edu/download/29327572/fairhurst2009.pdf

FAO, 2017. FAOSTAT Production Statistics. Food and Agricultural Organization of the United Nations, Rome.

Färe, R., \& Primont, D. (1995). Distance functions. In Multi-Output Production and Duality: Theory and Applications (pp. 7-41). Springer, Dordrecht. https://doi.org/10.1007/978-94-011-0651$1 \_2$

Farrell, M. J. (1957). The measurement of productive efficiency. Journal of the Royal Statistical Society: Series A (General), 120(3), 253-281.

Ferreira, M. D. P., \& Féres, J. G. (2020). Farm size and Land use efficiency in the Brazilian Amazon. Land Use Policy, 99, 104901. https://doi.org/10.1016/j.landusepol.2020.104901 
Fitzherbert, E. B., Struebig, M. J., Morel, A., Danielsen, F., Brühl, C. A., Donald, P. F., \& Phalan, B. (2008). How will oil palm expansion affect biodiversity?. Trends in ecology \& evolution, 23(10), 538-545. . doi:10.1016/j.tree.2008.06.012

FoE. (2005) Palm oil-rainforest in your shopping. Friends of the Earth Trust (FoE), London. Available via URL. http://www.foe.co.uk/campaigns/biodiversity/case_studies/palmoil_index.html. Accessed Sep 2020

FWI. (2014). Lembar Fakta: Pengabaian Kelestarian Hutan Alam dan Gambut, serta Faktor Pemicu Konflik Lahan yang Berkelanjutan. Bogor: Forest Watch Indonesia. (Accessed: 29 juli 2020.)

FWI. (2018). Angka deforestasi sebagai "Alarm" memburuknya hutan Indonesia. http://fwi.or.id/publikasi/angka-deforestasi-sebagai-alarm-memburuknya-hutanindonesia/\#: (Accessed: 29 Juli 2020)

Gaworecki M (2016) Norway Commits to Zero Deforestation. Mongabay, 26 May.

Germer, J., \& Sauerborn, J. (2008). Estimation of the impact of oil palm plantation establishment on greenhouse gas balance. Environment, Development and Sustainability, 10(6), 697-716.

Greenpeace (2007) Palm oil: cooking the climate. Greenpeace International, Amsterdam. Available via URL. http://www.greenpeace.org/international/news/palm-oil_cooking-the-climate. Accessed Sep 2020.

Hoffmann, M. P., Donough, C., Oberthür, T., Vera, A. C., Wijk, M. T. V., Lim, C. H., ... \& Whitbread, A. M. (2015). Benchmarking yield for sustainable intensification of oil palm production in Indonesia using PALMSIM. The Planter, 91(1067), 81-96. http://oar.icrisat.org/id/eprint/9301

Islam, M. S., Hui Pei, Y., \& Mangharam, S. (2016). Trans-boundary haze pollution in southeast asia: sustainability through plural environmental governance. Sustainability, 8(5), 499.https://www.mdpi.com/20711050/8/5/499

Irz, X. T., \& Hadley, D. (2003). Dual Technological Development in Botswana Agriculture-A Stochastic Input Distance Approach (No. 1002-2016-78302). 10.22004/ag.econ.25899

Irz, X., \& Thirtle, C. (2004). Dual technological development in Botswana agriculture: A stochastic input distance function approach. Journal of Agricultural Economics, 55(3), 455-478. https://doi.org/10.1111/j.1477-9552.2004.tb00110.x

Koh, L. P., \& Wilcove, D. S. (2008). Is oil palm agriculture really destroying tropical biodiversity?. Conservation letters, 1(2), 60-64. https://doi.org/10.1111/j.1755263X.2008.00011.x

Koh, L. P., Ghazoul, J., Butler, R. A., Laurance, W. F., Sodhi, N. S., Mateo-Vega, J., \& Bradshaw, C. J. (2010). Wash and spin cycle threats to tropical biodiversity. Biotropica, 42(1), 67-71. https://www.jstor.org/stable/27742864

Koplitz, S. N., Mickley, L. J., Marlier, M. E., Buonocore, J. J., Kim, P. S., Liu, T., ... \& Pongsiri, M. (2016). Public health impacts of the severe haze in Equatorial Asia in September-October 2015: demonstration of a new framework for informing fire management strategies to reduce downwind smoke exposure. Environmental Research Letters, 11(9), 094023. http://dx.doi.org/10.1088/1748-9326/11/9/094023

Lovell, C.A.K., Richardson, S., Travers, P., Wood, L., (1994). Resources and functionings: a new view of inequality in Australia. In: Eichhorn, W. (Ed.), Models and Measurement of Welfare and Inequality. Springer-Verlag, Berlin. https://doi.org/10.1007/978-3-642-79037-9_41

Meijaard, E., Sheil, D., (2013). Oil-palm plantations in the context of biodiversity conservation. In: In: Levine, S. (Ed.), Encyclopedia of Biodiversity, vol. 5. Academic Press, Waltham, MA, pp. 600-612. https://doi.org/10.1016/j. envsci.2019.08.004

Nguyen, H. Q. (2017). Analyzing the economies of crop diversification in rural Vietnam using an input distance function. Agricultural systems, 153, 148-156. https://doi.org/10.1016/j.agsy.2017.01.024

Pacheco, P., Schoneveld, G., Dermawan, A., Komarudin, H., \& Djama, M. (2020). Governing sustainable palm oil supply: Disconnects, complementarities, and antagonisms between state 
regulations and private standards. Regulation \& Governance, 14(3), 568598. https://doi.org/10.1111/rego.12220

Polasky, S., Nelson, E., Camm, J., Csuti, B., Fackler, P., Lonsdorf, E., ... \& Haight, R. (2008). Where to put things? Spatial land management to sustain biodiversity and economic returns. Biological conservation, 141(6), 1505-1524. https://doi.org/10.1016/j.biocon.2008.03.022

Pye, O., Daud, R., \& Harmono, Y. (2012). Precarious lives: Transnational biographies of migrant oil palm workers. Asia Pacific Viewpoint, 53(3), 330-342. https://doi.org/10.1111/j.14678373.2012.01496.x

Rasmussen, S. (2010). Scale efficiency in Danish agriculture: an input distance-function approach. European Review of Agricultural Economics, 37(3), 335-367. https://doi.org/10.1093/erae/jbq023

Reddy, N. B. K., \& Ramanaiah, Y. V. (1985). Changes in agricultural land use efficiency in Andhra Pradesh: A study by the Standard Coefficient method. Land Use Policy, 2(3), 210-216. https://doi.org/10.1016/0264-8377(85)90069-9

Rist, L., Feintrenie, L., \& Levang, P. (2010). The livelihood impacts of oil palm: smallholders in Indonesia. Biodiversity and conservation, 19(4), 1009-1024. https://doi.org/10.1007/s10531010-9815-z

RSPO (2018). About us. Roundtable on Sustainable Palm Oil, Kuala Lumpur, URL: https://rspo.org/about.

Saharjo, B. H., Putra, E. I., \& Atik, U. (2012). Pendugaan Emisi CO2 Sebagai Gas Rumah Kaca Akibat Kebakaran Hutan dan Lahan pada Berbagai Tipe Penutupan Lahan di Kalimantan Tengah Tahun 2000-2009. Jurnal Jurnal Silvikultivar Tropika, 3, 143-148. https://core.ac.uk/download/pdf/230360250.pdf

Sundaraja, C. S., Hine, D. W., \& Lykins, A. (2020). Confronting the palm oil crisis: Identifying behaviours for targeted interventions. EnvironmentalScience \& Policy, 103, 99-106. https://doi.org/10.1016/j.envsci.2019.08.004

Susanti, A., \& Maryudi, A. (2016). Development narratives, notions of forest crisis, and boom of oil palm plantations in Indonesia. Forest Policy and Economics, 73, 130-139. https://doi.org/10.1016/j.forpol.2016.09.009

Sheil, D., Casson, A., Meijaard, E., Van Noordwijk, M., Gaskell, J., Sunderland-Groves, J., ... \& Kanninen, M. (2009). The impacts and opportunities of oil palm in Southeast Asia: What do we know and what do we need to know? (Vol. 51). Bogor, Indonesia: Center for International Forestry Research. http://dlc.dlib.indiana.edu/dlc/handle/10535/5256

Shephard, R.W., 1970, Theory of cost and production functions (Princeton University Press, Princeton).

The Royal Society (Great Britain). (2009). Geoengineering the climate: Science, governance and uncertainty. Royal Society. https://eprints.soton.ac.uk/156647/

Varkkey, H., Tyson, A., \& Choiruzzad, S. A. B. (2018). Palm oil intensification and expansion in Indonesia and Malaysia: Environmental and socio-political factors influencing policy. Forest Policy and Economics, 92, 148-159. https://doi.org/10.1016/j.forpol.2018.05.002

Vermeulen, S., \& Goad, N. (2006). Towards better practice in smallholder palm oil production. lied.

Wang, L., \& Li, H. (2014). Cultivated land use efficiency and the regional characteristics of its influencing factors in China: By using a panel data of 281 prefectural cities and the stochastic frontier production function. Geographical Research, 33(11), 1995-2004.

Wicke, B., Sikkema, R., Dornburg, V., \& Faaij, A. (2011). Exploring land use changes and the role of palm oil production in Indonesia and Malaysia. Land use policy, 28(1), 193-206. https://doi.org/10.1016/j.landusepol.2010.06.001

Wilcove, D. S., \& Koh, L. P. (2010). Addressing the threats to biodiversity from oil-palm agriculture. Biodiversity and conservation, 19(4), 999-1007. https://doi.org/10.1007/s10531009-9760-x 
Woittiez, L. S. (2019). On yield gaps and better management practices in Indonesian smallholder oil palm plantations (Doctoral dissertation, Wageningen University).https://library.wur.nl/ WebQuery/wurpubs/549795

WWF Indonesia (2008). deforestation forest degradation, biodiveristy loss and C02 emissions in riau sumatera

indonesia.https://wwfeu.awsassets.panda.org/downloads/riau_co2_report_wwf_id_27feb 08_en_Ir_.pdf

Zhou, Z. M. (2012). Study on Cultivated Land Resources Use Efficiency in Henan. In Advanced Materials Research (Vol. 356, pp. 2921-2924). Trans Tech Publications Ltd. https://doi.org/10.4028/www.scientific.net/AMR.356-360.2921 